\title{
LINGKUNGAN SEBAGAI MEDIA PENUNJANG EFEKTIVITAS PEMBELAJARAN BAHASA ARAB DI PONDOK PESANTREN AL-IMAN PONOROGO
}

\author{
Abdul Qodir Jailani ${ }^{1}$, dan Ahmad Minhajul Abror ${ }^{1^{*}}$ \\ ${ }^{1}$ Pascasarjana UIN Maulana Malik Ibrahim Malang
}

\begin{abstract}
This study aims to determine the environment as learning media of Arabic teaching, in two cases: (1) the important role; (2) the advantage \& disadvantage advantages and disadvantages in utilizing the environment. Research conducted in in the 'Al-Iman' Islamic Boarding School, Ponorogo. The method used is descriptivequalitative. The results indicate that: (1) The environment has an important role as a medium to support the effectiveness of Arabic learning, through the design of Arabic language habituation activities in the Boarding school environment. (2) The advantage and disadvantage can be identified in the use of the environment as a medium for learning Arabic. The advantages are: a) learning activities are more interesting and not boring, b) the nature of learning will be more meaningful, c) learning activities are more comprehensive and more active , d) learning resources become richer, e) students are also more able to understand and appreciate the aspects of life in their environment. The drawbacks are: a) limited preparation, b) there is an assumption that learning in the environment requires a relatively long time, c) many teachers still have a narrow view that learning is only done in the classroom.
\end{abstract}

Keywords: The role of the environment, learning media of Arabic, arabic learning

*Korespondensi Penulis: ahmadabror30@gmail.com 


\begin{abstract}
Abstrak: Penelitian bertujuan untuk mengetahui lingkungan sebagai media pembelajaran bahasa Arab dalam dua hal: (1) peran pentingnya, dan (2) kelebihan serta kekurangan dalam pemanfaatan lingkungan tersebut. Penelitian dilakukan di Pondok Pesantren Al-Iman Ponorogo. Metode yang digunakan adalah kualitatif deskriptif. Hasilnya menunjukkan bahwa: (1) lingkungan memiliki peran penting sebagai media penunjang efektivitas pembelajaran bahasa Arab, melalui desain kegiatan-kegiatan pembiasaan berbahasa Arab di lingkungan pondok. (2) Dapat diidentifikasi kelebihan dan kekurangan dalam pemanfaatan lingkungan sebagai media pembelajaran bahasa Arab. Kelebihannya : a) kegiatan belajar lebih menarik dan tidak membosankan, b) hakikat belajar akan lebih bermakna, c) kegiatan belajar lebih komprehensif dan lebih aktif, d) sumber belajar menjadi lebih kaya e) siswa juga lebih dapat memahami dan menghayati aspekaspek kehidupan yang ada di lingkungannya. Adapun kekurangannya: a) persiapan yang terbatas, b) adanya anggapan belajar dengan lingkungan memerlukan waktu yang relatif lama, c) banyak guru yang masih berpandangan sempit bahwa belajar hanya dilakukan di dalam kelas.
\end{abstract}

\title{
Kata Kunci: Peran Lingkungan, Media Pembelajaran Bahasa Arab, arabic learning
}

\section{A. Pendahuluan}

Proses belajar mengajar adalah proses komunikasi. Dalam proses komunikasi tersebut, terdapat tiga komponen yang berperan didalamnya, yaitu kurikulum sebagai pesan yang disampaikan, guru sebagai penyampai pesan atau komunikator dan siswa sebagai penerima pesan atau komunikasinya. Agar proses belajar mengajar tersebut berjalan efektif dan efisien maka perlu alat bantu yang yang dikenal dengan sebutan media pembelajaran. ${ }^{1}$ Ada beberapa pengertian mengenai media pembelajaran, diantaranya adalah media pembelajaran mencakup setiap orang, materi dan peristiwa yang digunakan siswa untuk memperoleh ilmu pengetahuan, sikap dan ketrampilan. Ada pendapat lain yang

1 Abdul Wahab Rosyidi dan Mamlu'atul Ni'mah, Memahami Konsep Dasar Pembelajaran Bahasa Arab (UIN-Maliki Press, 2011), hlm. 101. 
mengatakan bahwa media pembelajaran adalah alat yang digunakan untuk menyampaikan suatu materi, bisa berupa buku, kamera, recorder, gambar, video, grafik dan masih banyak lagi.

Penggunaan media pembelajaran memiliki tuhuan utama yaitu agara pesan yang berupa materi pembelajaran dapat diserap dengan maksimal oleh siswa yang disini berperan sebagai penerima informasi. Dengan menggunakan media tersebut, materi yang disampaikan dapat diterima dengan baik, cepat dan mudah oleh siswa. Dia juga bisa memproses materi yang telah disampaikan secara singkat tanpa memerlukan proses yang panjang na menyebabkan kejenuhan bagi siswa saat mengikuti proses pembelajaran. ${ }^{2}$

Media pembelajaran lingkungan adalah sebuah pemahaman terhadap tingkah laku atau gejala dari suatu obyek atau pengamatan ilmiah terhadap semua yang ada di sekitar sebagai bahan pembelajaran siswa baik sebelum dan sesudah menerima materi dari sekolah dengan memanfaatkan lingkungan sebagai ajang untuk membawa pengalaman dan penemuan mereka. ${ }^{3}$ Lingkungan merupakan salah satu bagian penting dalam kegiatan belajar mengajar, termasuk dalam kegiatan belajar mengajar bahasa arab. Lingkungan yang baik dan kondusif akan mendukung keberhasilannya kegiatan belajar mengajar.

Media pembelajaran yang kurang mendukung juga menjadi permasalahan tersendiri bagi sebagian lembaga pendidikan. Melihat bahasa arab adalah bahasa asing dan tidak bisa dipelajari secara instan, maka perlu adanya media yang mendukung kelancaran pembelajaran tersebut. Dengan minimnya media bagi sebagian lembaga pendidikan, pmbelajaran bahasa arab belum bisa optimal. Kasus seperti ini banyak terjadi di daerah pedesaan dimana teknologi belum merata, apalagi banyak juga terdapat guru yang masih belum melek teknologi sehingga hal ini menjadi kendala keberhasilan dalam pembelajaran bahasa arab. Untuk

2 Syaiful Bahri Djamarah dan Aswan Zain, Strategi belajar mengajar (Jakarta: Rineka Cipta, 2010), hlm. 7.

${ }^{3}$ Acep Hermawan, Metodologi Pembelajaran Bahasa Arab (Bandung: PT Remaja Rosdakarya, 2011), hlm. 30. 
mensiasati hal tersebut, sebagian lembaga pendidikan membuat sebuah inovasi dalam pembelajaran bahasa dengan teknologi yang sederhana, yaitu menciptakan lingkungan bahasa, termasuk yang ada di Pondok Pesantren Al-Iman Ponorogo. Atas dasar inilah, peneliti tertarik untuk meneliti tentang bagaimana peran lingkungan sebagai media pembelajaran bahasa arab di Pondok Pesantren Al-Iman Ponorogo.

Sebelumnya telah ada beberapa penelitian mengenai lingkungan bahasa, diantaranya adalah penelitian yang dilakukan oleh Muhammad Amiruddin dan Ukhti Roudhotul Jannah yang berjudul "Peran Lingkungan Bahasa Inggris Lisan Siswa Pondok Pesantren Paiton", Penelitian tersebut fokus pada pengaruh lingkungan terhadap pembelajaran bahasa inggris. Selanjutnya adalah penelitian yang dilakukan oleh Anwar Sadat yang berjudul "Lingkungan Bahasa Sebagai Media Pembelajaran Bahasa Arab", penelitian tersebut bersifat universal, yaitu membangun pembelajaran bahasa arab yang efektif dan produktif. Yang ketiga adalah penelitian yang dilakukan oleh Lilis Sumaryanti yang berjudul "Peran Lingkungan Terhadap Bahasa Anak", penelitian tersebut fokus pada pembahasan proses pemerolehan bahasa anak melalui lingkungan. Yang membedakan penelitian peneliti dengan penelitian terdahulu adalah pada ruang lingkup dan obyeknya.

\section{B. Kajian Literatur}

\section{Peran Lingkungan Sebagai Media Pembelajaran Bahasa Arab}

Lingkungan merupakan segala sesuatu atau kondsi pada suatu tempat. Keberadaan lingkungan mempengaruhi aktivitas makhluk hidup didalamnya, termasuk manusia. Dalam hal ini bisa diartikan bahwa lingkungan bisa memberikan dampak pada pemerolehan bahasa seseorang. Lingkungan di sini memiliki arti banyak hal, mulai dari keadaaan geografisnya, cuaca, sampai sosial masyarakatnya. Dalam pemerolehan bahasa, lingkungan berperan sebagai media untuk melatih dan membiasakan penggunaan bahasa tersebut. Ibnu Jinni 
menjelaskan bahwa pada awalnya manusia mempelajarai bahasa dari alam melalui gemericik air, desir angina dan suara hewan. Dari situlah manusia sadar akan kemampuan alat ucapnya sehingga muncullah bahasa, dan bahasa tersebut dipelajari dari kehidupan sehari-hari mereka. ${ }^{4}$

Melihat pembelajaran bahasa arab di Indonesia, peneliti membaginya menjadi dua bagian, yaitu pembelajaran bahasa secara literasi dan pembelajaran bahasa arab sebagai bahasa komunikasi. Pembelajaran bahasa arab secara literasi bisa dilihat di berbagai Pondok Pesantren salaf, yang mempelajari bahasa arab untuk mempelajarai teks agama, baik berupa Al-Qur'an, Hadits dan kitab-kitab turots, dan hal ini membutuhkan pengetahuan tentang kaidah-kaidah nahwiyah maupun shorfiyyah yang memadai Sedangkan untuk pembelajaran bahasa sebagai komunikasi tidak cukup hanya belajar tentang kaidah-kaidah kebahasaan saja, akan tetapi juga membuttuhkan pembiasaan yang sering dan diulang-ulang agar tesbiasa untuk berinteraksi dengan bahasa arab. Bahkan dalam metode pembelajaran bahasa sebagai bahasa komunikasi seringkali mengabaikan kaidahkaidah kebahasaan dan memfokuskan pada pembiasaan saja. Disinilah ligkungan memiliki peran terhadap pembelajaran bahasa. Bahasa sebagai kebiasaan jika tidak dilatih dengan lingkungan yang mendukung maka hasilnya pun kurang maksimal.

\section{Prinsip-Prinsip Pemanfaatan Lingkungan}

Lingkungan belajar ibarat laboratorium dan merupakan tempat mengembangkan pengetahuan, ketrampilan dan bakat bagi siswa. Maka laboratorium itu harus mampu menjadi pendorong semangat siswa, menjadi tempat eksperimen, mampu menjadi sumber belajar, menjadi tempat pengembangan kualitas kebahasaan, menjadi tempat pemecah masalah, tempat

${ }^{4}$ Arifuddin, “Pemikiran-Pemikiran Fonetik Ibnu Jinni (W. 392 H./1002 M.)," Jurnal CMES 6, no. 2 (2013): hlm. 154. 
penyalur ekspresi dan lain sebagainya. ${ }^{5}$ Untuk mewujudkan laboratorium seperti tersebut diatas juga membutukan peran guru sebagai fasilitator dan pendamping siswa selain sebagai pengajar. Selain itu juga perlu memperhatikan beberapa prinsip berikut : 6

a. Merefleksikan selera siswa

Lingkungan belajar bahasa harus bisa menarik bagi siswa. Oleh karena itu dalam desainnya sebisa mungkin mempertimbangkan perasaan, minat, dinamika dan karateristik siswa. Maksudnya, lingkungan belajar bahasa arab yang ada perlu diselaraskan dengan perkembangan dan menyesuaikan dengan ada yang disukai oleh siswa. Pembelajaran bahasa jika tidak digunakan media yang sesuai akan menimbulkan kebosanan bagi siswa. Apalagi jika pembelajaran hanya fokus di kelas dan materinya tidak dikemas dengan baik, oleh karena itu dengan lingkungan yang menarik, siswa bisa antusias dan fokus terhadap pembelajaran. Jika dirasa penggunaan media interaktif belum bisa menari minat siswa, maka lingkungan inilah yang akan menjadi pendorong nan pemacu semangat siswa.

b. Optimalisasi belajar dan perkembangan siswa

Tujuan dalam pembelajaran sangat pentng untuk diperhatikan mengingat tujuan tersebut sebagai acuan dalam proses pembelajaran. Untuk mencapai tujuan tersebut dibutuhkan optimalisasi belajar dan perkembangan siswa. Selain itu pembelajaran juga harus berorientasi pada cara belajar dan kondisi serta kebutuhan siswa. Penekanan dalam prinsip ini adalah bagaimana mengembangkan seluruh potensi yang ada dalam diri siswa. Potensi yang terpendam tersebut bisa tergali karena dua factor, yaitu dari dalam diri siswa itu sendiri dan dari luar, yakni lingkungan siswa tersebut. Jika seluruh potensi siswa bisa berkembang dengan optimal maka pembelajaran bahasa juga akan menjadi mudah. Terkadang ada

${ }^{5}$ Anwar Sadat, "Lingkungan Bahasa sebagai Media Pembelajaran Bahasa Arab (Ikhtiar membangun Pembelajaran Yang Efektif dan Produktif)," AL-AF'IDAH: Jurnal Pendidikan Bahasa Arab dan Pengajarannya 1, no. 1 (2017): 4-29.

${ }^{6}$ Rita Mariyana, Pengelolaan lingkungan belajar (Jakarta: Prenada Media Grup, 2010), hlm. 25. 
siswa yang memiliki shor termt memory (memori jangka pendek). Dengan prinsip ini bisa membantu siswa yang awalnya memiliki short term memory (memori jangka pendek) menjadi long term memory (memori jangka panjang). Dan hasil akhirnya adalah bagaimana siswa bisa mengorganisir pesan-pesan pembelajaran baik dari sisi afektif, kognitif dan psikomotorik.

c. Berpijak pada efisiensi pembelajaran bahasa

Seluruh keguatan pembelajaran harus dilakukan dengan produktif dan sesuai dengan kadar siswa, tidak terlalu berlebihan sehingga membebani siswa dan tidak terlalu sedikit sehingga siswa akan meremehkan. Ketepatan kadar pembelajaran disini diperlukan agar siswa bisa mendapat porsinya dengan tepat. Pembelajaran yang terlalu banyak dan menuntu berbagai hal pada siswa akan mengakibatkan siswa menjadi malas bahkan bisa sampai memberontak, karna secara otak tidak bisa menyerap semua pengetahuan yang diberikan. Begitu juga dengan lingkungan, lingkungan yang terlalu memaksa siswa untuk belajar, hanya akan menyebabkan siswa semakin membenci pembelajaran tersebut. Yang seharusnya diperhatikan adalah efisiensi waktu dan kondisi. Oleh karena itu, lingkungan ang dibentuk saat pembelajaran bahasa siswa harus dibuat senyaman mungkin. Siswa yang sudah merasa nyaman dengan lingkungan pembelajarannya secara alami akan mudah untuk diarahkan dan diberi materi.

\section{Metode Penelitian}

Penelitian ini termasuk penelitian kualitatif. Creswell menjelaskan penelitian kualitatif didefinisikan sebagai suatu pendekatan atau penelusuran untuk mengeksplorasi dan memahami suatu gejala sentral. ${ }^{7}$ Teknik pengambilan data yang dilakukan melalui dokumentasi; wawancara tersruktur dan semi terstruktur, dengan memanfaatkan media google form, dan media sosial penunjang lainnya. Penggunaan google form ini dikarenakan google form lebih cepat dan luas untuk

7 Dalam Subana dan Sudrajat, Dasar-dasar Penelitian Ilmiah (Bandung: Pustaka Setia, 2005), hlm. 20. 
melakukan wawancara kepada subjek, di sisi lain karena adanya kebijakan social distancing, maka tidak memungkinkan jika kami menggunakan metode wawancara secara langsung. Subjek penelitian ini siswa yang ada di pondok pesantren Al-Iman Ponorogo. Uji keabsahan data menggunakan triangulasi sumber dan teknik. Penelitian difokuskan pada peran lingkungan sebagai media penunjang efektivitas pembelajaran bahasa Arab. Analisis data dilakukan menggunakan model interaksi Miles \& Hubberman: Reduksi data, display data dan verifikasi data. Hasil analisis data disajikan dengan teknik informal.

\section{Hasil dan Pembahasan}

\section{Profil Pondok Pesantren (Ponpes) Al-Iman Ponorogo}

Pondok Peantren Al-Iman terletak di kabupaten Ponorogo Jawa timur. Lembaga ini didirikan oleh (Alm) KH. Mahfudz Hakiem pada tahun 1421 Hjriyah atau tahu 1991 masehi, Pondok Pesantren ini tergolong Pondok modern. Visi misi yang dicanangkan oleh Pondok Pesantren ini berorientasi untuk mempersiapkan kader-kader islam yang militant dan siap berjuang diberbagai lini pada segala tuntutan zaman. Oleh karena itu Lembaga Pendidikan tersebut mengintegrasikan antara PQ (Physical Quotient), IQ (Intelegent Quotient), SQ (Spiritual Quotient) dan EQ (Emotional Quotient), dengan tujuan untuk memantapkan akidah dan kedalaman spiritual, keluasn IPTEK dan akhlakul karimah guna membentuk siswa yang benar-benar matang di masa mendatang.

Format pendidikan yang ada di Pondok Pesantren Al-Iman Ponorogo ada mulai jenjang KMI (Kulliyatul Mu'allimin wal Mu'allimat Al-Islamiyah) yang setara dengan MTs dan MA, persamaan MTs (Terakreditasi A) dan MA (terakreditasi B). kurikulum yang digunakan adalah kurikulum terpadu dan sudah terintegrasi dengan spesifikasi ilmu dakwah dan keguruan. Kurikulum yang disusun menginduk pada landasan filosofi dengan perpaduan antara kurikulum Pondok Modern Gontor, kurikulum 2013, ditambah dengan kurikulum salaf dengan jenjang pendidikan masa belajar SD/MI 6 tahun dan SMP keatas 4 tahun. Selain itu, 
Pondok Pesantren Al-Iman juga mengembangkan kemampuan life skill yang harus dikuasai oleh seluruh siswa, sert mengembangkan pendidikan yang berorientasi internasional dengan tetap mempertahankan budaya local.

Selain mempelajari ilmu agama, di Ponpok Psantren Al-Iman Ponorogo juga mempelajari bahasa asing seperti bahasa arab dan inggris, dan ini yang menjadi daya tarik Pondok Pesantren tersebut. Dalam pembelajaran bahasa arab, Pondok Pesantren ini memiliki cara khusus, yaitu dengan memanfaatkan lingkungan Pesantren sebagai media pembelajaran bahasa arab. Penggunaan ligkungan ini dirasa efektif karena pembelajaran bahasa arab yang notabennya bahasa asing, akan sulit dipelajari jika tidak ada lingkungan mendukung. Dengan kemampuan kebahasaan dan kondisi lingkungan yang mendukung, diharapkan proses pembelajaran bahasa arab akan berjalan dengan baik dan sempurna. Tujuan dari dibentuknya lingkungan ini adalah untuk mengembangkan kemampuan bergaul (Soft Skill) anak dalam mengekspresikan dan mengaktualisasikan pikiran mereka melalui bahasa. ${ }^{8}$

\section{Peran Lingkungan Sebagai Media Penunjang Efektivitas Pembelajaran Bahasa Arab di Pondok Pesantren Al-Iman Ponorogo.}

Secara teori pemerolehan bahasa, baik bahasa pertama dan kedua mengacu paa banyak teori. Akan tetapi yang paling mendasar adalah teori behaviorisme dan kognitivisme. Teori behaviorisme berpendapat bahwa pada awalnya seseorang lahir dalam keadaan tidak memiliki apa-apa, sehingga peran lingkungan sangat penting dalam pemerolehan bahasa. Dengan kata lain, lingkunganlan yang banyak memiliki sumbangsih besar kepada pemerolehan bahasa seseorang. Sebagaimana teori behaviorisme, teori kognitivisme bernaggapan bahwa dalam pencapaian proses intenal anak ada peran penting dari minat, dan minat tersebut adalah hadil

8 Lilis Sumaryanti, "Peran Lingkungan terhadap Perkembangan Bahasa Anak," Muaddib: Studi Kependidikan dan Keislaman 7, no. 01 (2017): 72-89. 
dari stimulus lingkungan. ${ }^{9}$ Terlepas dari kedua teori tersebut tidak bisa dipungkiri bahwa lingkungan memiliki peran yang penting dalam pemerolehan bahasa, apalagi bahasa kedua. Lingkungan akan menyediakan berbagai macam materi tentnag bahasa dimana pun da berada. Jika dia berada di lingkungan yang tepat, maka pemerolehan bahasa nya pun akan sempurna.

Menurut Krashen dalam bukunya Efendy "Metodologi Pengajaran Bahasa Arab" menjelaskan bahwa dalam proses pembelajaran bahasa yang berkaitan dengan lingkungan Ada dua cara yang terkenal, yaitu pemerolehan bahasa (Language Acquisition) dan pembelajaran bahasa (Languange Learning). ${ }^{10}$ Language Acquisition adalah proses penguasaan bahasa secara tidak sadar, melalui alam bawah sadar dengan berinteraksi langsung dengan pengguna bahasa tersebut. Sedangkan Language Learning adalah proses penguasaan bahasa secara sadar, yaitu dengan mempelajari kaidah-kaidah bahasa dan cara penggunaannya dengan arahan dari guru maupun belajar mandiri di lembaga pendidikan.

Kedua cara diatas diterapkan dalam pembelajaran bahasa arab di Pondok Pesantren Al-Iman Pnorogo, mengajarkan bahasa arab secara kaidah-kaidah nahwiyah dan shorfiyah dan membuat sebuah lingkungan (Bi'ah Lughowiyyah) untuk menunjang pembelajaran sisiwa. Ada beberapa metode yang digunanakan dalam menunjang pembelajaran siswa di pondok pesantren Al-Iman Ponorogo, antara lain yaitu :

a. Study Tour

Study Tour adalah kunjungan dari siswa Pondok Pesantren Al-Iman keluar pondok, bisa ke lembaga lain atau destinasi apapun yang telah direncanakan sebelumnya untuk mempelajari hal baru yang relevan dengan kegiatan Pondok Pesantren Al-Iman Ponorogo. Sebelum pemberangkatan, pada jauh-jauh hari sudah dipersiapkan apa yang akan dilakukan dan kemana tujuan pembelajaran

9 Andiopenta Purba, "Peranan lingkungan bahasa dalam pemerolehan bahasa kedua," Pena: Jurnal Pendidikan Bahasa dan Sastra 2, no. 2 (2013).

${ }^{10}$ Ahmad Fuad Effendy, Metodologi Pengajaran Bahasa Arab (Malang: Misykat, 2005), hlm. 221.

Tarbiyatuna: Jurnal Pendidikan Ilmiah Vol. 5 No. 2 (Desember) 2020 | 192 
Pondok Pesantren. Biasanya kunjungan ini dilaksanakan setiap akhir semester agar tidak mengganggu pembelajaran siswa di sekolah, selain itu siswa akan dibagi ke beberapa small group dan masing-masing small group dibimbing oleh seorang guru untuk mengarahkan jalannya kunjungan agar tidak melebar kemana-mana. Misalnya tema pembelajarannya tentang alam, maka siswa akan diajak untuk pergi pantai atau pegunungan sambil belajar tentang alam menggunakan bahasa arab. Kegiatan ini dirasa efektif karena selain belajar para siswa juga diajak bermain dan refreshing , sehingga pembelajaran bahasa arab menjadi lebih menyenangkan.

b. Mendatangkan Ahli Bahasa

Jika cara pertama siswa diajak berkunjung ke suatu tempat, pada agenda ini akan didatangkan beberapa nrasumber dan diundang untuk mengisi sebuah forum di Pondok Pesantren. Narasumber-narasumber ini akan memberikan pengetahuan baru kepada para siswa mengenai pembelajaran bahasa arab. Narasumber bisa berasal dari dalam maupun luar negeri tergantung kebutuhan dari siswa akan materi yan akan diajarkan. Jika narasumber berasal dari dalam negeri biasanya pihak pengurus akan mengundang beberapa ahli dibidang pendidikan dan akan memaparkan bagaimana pembelajaran yang menyenangkan itu dilakukan.. selain itu Biasanya juga dari pihak pengurus siswa akan mengudang tokoh dari luar maupun orang Indonesia yang sudah hidup lama di arab, seperti mahasiswa yang kulah di mesir dan Saudi. Nantinya para narasumber tersebut akan mengajari siswa bermuhadatsah baik secara fusha (baku) maupun secara amiyah (pasaran). Di agenda tersebut narasumber juga akan memberikan motivasi kepada para siswa agar mereka semakin giat dan semangat untuk mempelajari bahasa arab.

c. Kemah Bahasa

Kemah bahasa ini dilaksanakan dua kali dalam satu semester, karena selain membutuhkan persiapan yang lumayan lama, agenda ini juga perlu meninjau keadaaan tempat yang akan digunakan berkemah terlebih dahulu. Siswa juga sebelumnya akan dibekli dan dibreefing dengan materi seputar kepramukaan dan pengetahuan tentang alam. Dalam agenda kemah bahasa tersebut siswa 
melakukan beberapa kegiatan seperti outbond, hiking, surviving, dan lain sebagainya, dan semua itu menggunakan bahasa arab. Jadi selama kemah bahasa yag dilaksanakan kurang lebih 3 hari, siswa mendapat banyak mufrodat baru dan pengalaman yang menyenangkan. Di malam terakhir kemah bahasa, para siswa yang sudah dibagi menjadi beberapa kelompok, masing-masing kelompok akan menampilkan pertunjukkan seni, bisa berupa drama, menyanyi, puisi dan lain sebagainya. Sesi pertunjukkan seni tersebut menjadi daya tarik tersendiri bagi para siswa, karena selain melatih mental dan kekompakkan mereka, pertunjukkan tersebut menjadi motivasi bahwa belajar bahasa arab tidak selalu monoton. Setelah selesai berkemah, hasilnya dibawa ke pondok pesantren untuk dibahas dan dipelajari bersama-sama dengan menggunakan bahasa Arab tentunya.

Adapun beberapa langkah yang digunakan untuk menjadikan lingkungan sebagai media dalam pembelajaran bahasa Arab di pondok pesantren Al-Iman Ponorogo, antara lain yaitu semua lingkungan yang ada di sekitar pondok pesantren bisa kita digunakan sebagai media pembelajaran, diantara caranya adalah sebagai berikut.

a. Labelisasi

Salah satu modal dalam mempelajari bahasa arab adalah perbendaharaan kosakata yang banyak sehingga mudah untuk menyebutkan dan menunjukkan makna kosakata tersebut dalam bahasa arab. Kosa kata bisa didapat dari mengahafal kosa kata tersebut dari kamus, akan tetapi masih dianggap monoton, karena tidak semua siswa suka mengahafal dan tidak semua hafalan siswa kuat. ${ }^{11}$ Untuk mensiasati hal tersebut maka Pondok Pesantren Al-Iman Ponorogo membuat labelisasi.

Labelisasi adalah proses memberikan label atau nama pada setiap tempat atau benda yang sehari-hari ditemui baik di lingkunhan sekolah maupun dilingkungan rumah dengan menggunakan bahasa arab. Yang bertujuan agar siswa

\footnotetext{
${ }^{11}$ Ulin Nuha, Metodologi Super Efektif Pembelajaran Bahasa Arab (Yogyakarta: Diva Press, 2012), hlm. 34 .
} 
mudah untuk mengingat nama-nama tersebut dalam bahasa arab. Terlihat mudah, akan tetapi ini sangat efektif dalam memperkenalkan kosakata baru yang seharihari dijumpai tentunya dalam bahasa Arab. Semakin sering kita bertemu dengan label nama tersebut maka akan semakin mudah siswa mengingatnya. Dan ini menjadi bekal awal dalam berkomunikasi dengan bahasa Arab.

Pelabelan dilakukan pada semua benda yang ada di sekeliling lingkungan Pondok. Mulai dari kelas, kantin, asrama, lapangan, sampai kamar mandipun semua dilabeli dengan bahasa arab. Hal ini memudahkan siswa untuk mengingat arti kosa kata tanpa harus menghafalnya. Ketika siswa berada di kantin, dia akan menemukan berbagai kosa kata tentang kantin yang ditempel disemua benda yang ada disana, begitupun ketika melewati lapangan, masuk kelas, semua benda sudah ditempeli dengan kosakata bahasa arab. Hal ini juga memudahkan siswa ketka melakukan muhadatsah bersama teman-temannya, karena memang di Pondok Pesantren tersebut mewajibkan seluruh siswanya untuk bercakap menggunakan bahasa arab sebagai bahasa sehari-hari.

b. Menciptakan Lingkungan Berbahasa

Dalam menciptakan lingkungan berbahasa, yang mana bahasa Arab digunakan sebagai sarana komunikasi sehari-hari, dimulai dengan percakapanpercakapan sederhana, kata orang pintar bahasa adalah ucapan. maka tidak ada salahnya jika memperaktikan bahasa yang sedang dipelajari dalam percakapan sehari-hari terutama dengan sesama pembelajar bahasa khususnya bahasa arab.

Di pondok pesantren Al-Iman Ponorogo, para siswa biasa menggunakan bahasa Arab sebagai bahasa percakapan sehari-hari baik ketika kegiatan belajar mengajar, diperpustakaan atau saat di kantin, yang mana sebisa mungkin percakapan dilakukan dengan bahasa Arab. Para siswa bisa menggunakan bahasa non baku atau ammiyah dalam percakapan-percakapam santai, tujuannya agar siswa tidak hanya mempunyai berbahasa resmi atau fusho saja, akan tetapi juga bahasa Arab yang setiap hari dipakai dalam pergaulan santai sehari-hari. 
Mengingat penggunaan bahasa ammiyah lebih banyak dan beragam dalam masyarakat Arab.

Bahasa adalah praktek, maka semakin sering dibiasakan menggunakan bahasa Arab dalam percakapan harian maka akan semakin mudah pula menguasainya. Biasanya kelemahan para siswa disana adalah malu dan minder atau takut salah. Perasaan semacam ini harus dibuang jauh-jauh. Jika ini dirasa terlalu berat, mungkin perlu mencari seseorang yang selalu siap untuk selalu berkomunikasi dengan menggunakan bahasa Arab.

c. Out Door Class

Salah satu pemanfaatan lingkungan dalam proses pembelajaran bahasa Arab di pondok pesantren Al-Iman Ponorogo adalah dengan menciptakan kelas di luar ruangan, dengan kata lain belajar di alam terbuka, bisa dilakukan di kantin, di lapangan atau di gazebo. Out Door class bertujuan untuk mencari suasana baru yang segar dan mempermudah siswa menangkap materi bahasa Arab yang akan dipelajari. Siswa dibuatkan jadwal rutin belajar di luar ruangan. Usahan ini dilakukan untuk menciptakan suasana pembelajaran sesantai mungkin agar materi yang disampaikan dapat difahami dengan mudah oleh siswa.

Bentuk pemanfaatan lain dari Out door Class adalah siswa bisa langsung berinteraksi dengan bendanya. Dalam agenda terseut biasanya siswa akan diajak untuk bermuhadatsah dan syarhul asya' (menerangkan sesuatu) tentang benda yang ada di sekitarnya. Seperti contoh jika tema pembahasan mengenai almarofiqu fil madrosiyyah (sarana sekolah) maka siswa akan diajak berkeliling lingkungan sekolah sambil menerangkan benda yang telah ditentukan. Benda yang diterangkan pun merupakan benda yang familiar bagi siswa da nada di sekitar lingkungan sekolah, seperti kantin, lapangan, majalah dinding, perpustakaan dan lain sebagainya. 


\section{Kelebihan dan Kekurangan Lingkungan Sebagai Media Penunjang Efektivitas Pembelajaran Bahasa Arab di Ponpes Al-Iman Ponorogo}

Lingkungan dalam perannya sebagai media pembelajaran tentu memiliki hal positif dan negatif. Diantara dampak positifnya adalah siswa bisa memanfaatkan lingkungan sebagai media pembelajaran menjadi lebih nyata karena siswa dihadapkan langsung dengan keadaaan dan peristiwa secara alami, lebih nyata, faktual, sehingga mudah bagi siswa untuk memahami apa yang dipelajari dan tentunya dapat dipertanggung jawabkan. ${ }^{12}$ Adapun dampak negatifnya adalah tidak selalu lingkungan bisa digunakan sebagai media, bisa jadi karena factor alam tidak mendukung seperti jika tiba-tiba terjadi hujan atau keadaan lapangan yang tidak memungkinkan untuk dimanfaatkan sebagai media pembelajaran.

Diantara kelebihan penggunaan lingkungan sebagai media pembelajaran bahasa arab di Pondok Pesantren Al-Iman Ponorogo, antara lain :

a. Kegiatan belajar mengajar menjadi lebih menarik dan tidak monoton jika dibandingkan dengan pembelajaran yang dilakukan didalam kelas selama berjam-jam, sehingga siswa jadi lebih termotivasi untuk belajar dengan giat.

b. Hakikat dari pembelajaran akan lebih nyata dan bermakna karena siswa dihadapkan langsung keadaan yang sebenarnya, situasi faktual dan alami

c. Bahan-bahan yang bisa dipelajari lebih banyak dan kaya sehingga pengetahuan siswa akan lebih luas lagi.

d. Proses pembelajaran lebih aktif dan komperehensif karena siswa bisa melakukan banyak hal dengan berbagai cara seperti bertanya atau wawancara, mengamati, mendemonstrasikan suatu hal dan menguji fakta. Dan hal ini tentunya tidak bisa dilakukan didalam kelas.

e. Sumber pembelajaran menjadi lebih banyak karena lingkungan yang bisa digunakan beraneka ragam, mulai dari lingkungan alam, lingkungan sosial, lingkungan buatan dan lain sebagainya.

12 Suwana Pringgawidagda, Strategi Penguasaan Bahasa (Yogyakarta: Adicita Karya Nusa, 2002), hlm. 43. 
f. Siswa menjadi lebih bisa memahami dan menghayati aspek-aspek kehidupan yang ada di sekitarnya, sehingga secara tidak langsung bisa membentuk pribadi siswa menjadi lebiih peka, memupuk rasa cinta dan peduli terhadap lingkungan. Dan hal ini tentunya akan sulit dilakukan jika pembelajaran hanya terfokus di dalam kelas saja.

Adapaun kekurangan dari penggunaan lingkungan sebagai media pembelajaran bahasa arab di Pondok Pesantren Al-Iman Ponorogo adalah :

a. Membutuhkan persiapan yang ekstra dan harus benar-benar matang, tidak seperti di kelas yan mana siswa tinnggal duduk dan memerhatikan. Di kelas juga pengkodisian siswa akan lebih mudah karena hanya mencakup sbuah ruang kecil, hak ini akan berbeda jika pembelajaran dilakukan di luar kelas.pengkodisian siswa lebih sulit dan rawan terjadi hal-hal yang tidak diinginkan.

b. Pembelajaran di lingkungan cenderung lama, karena siswa membutuhkan waktu untuk memahami satu persatu, dan hal ini tentunya beda dengan pembelajaran di kelas yang cuku dengan sebuah buku dan media interaktif bias.

c. Maih ada sebagian guru yang kurang setuju dengan pembelajaran diluar kelas karena beranggapan bahwa pembelajaran efektis adalah pembeljaran yang ada di kelas, sedangkan diluar itu hanya main-main saja.

Dibalik semua kelebihan dan kekurangan yang telah disebutkan diatas, menurut hemat peneliti adalah bagaimana seorang guru bisa semaksimal mungkin memanfaatkan lingkungan sebagai media pembelajaran bahasa arab, sehingga dapat mengoptimalkan peran lingkungan sebagai madia tersebut. Selain itu, seorang guru juga harus dapat meminimalisir kekurangan-kekurangan dan kemungkinan buruk yang terjadi dalam proses pembelajaran menggunakan media lingkungan tersebut. 


\section{E. Kesimpulan}

Hasil penelitian menunjukkan peran penting lingkungan sebagai sarana penunjang efektivitas pembelajaran Bahasa Arab. Beberapa metode yang digunakan dalam aktivitas pemanfaatan lingkungan sebagai penunjang pembelajaran antara lain: Study Tour; Manusia sebagai Sumber; dan Kemah Bahasa. Beberapa langkah yang dapat digunakan untuk menjadikan lingkungan sebagai media dalam pembelajaran bahasa Arab adalah : Labelisasi; Menciptakan Lingkungan Berbahasa; dan Kelas Out Door.

Dalam penerapannya terdapat kelebihan-kelebihan yang dapat diidentifikasi dalam pemanfaatan lingkungan tersebut, antara lain: (1) Kegiatan belajar mengajar menjadi lebih menarik dan tidak monoton; (2) Hakikat dari pembelajaran akan lebih nyata dan bermakna; (3) Bahan-bahan yang bisa dipelajari lebih banyak dan kaya sehingga pengetahuan siswa akan lebih luas lagi; (4) Proses pembelajaran lebih aktif dan komperehensif; (5) Sumber pembelajaran menjadi lebih banyak karena lingkungan yang bisa digunakan beraneka ragam; Siswa menjadi lebih bisa memahami dan menghayati aspek-aspek kehidupan yang ada di sekitarnya. Meski demikian, terdapat sejumlah kekurangan yang membutuhkan solusi penanganan: (1) Membutuhkan persiapan yang ekstra dan harus benar-benar matang; (2) Pembelajaran di lingkungan cenderung lama; dan (3) Masih ada sebagian guru yang kurang setuju dengan pembelajaran diluar kelas karena beranggapan bahwa pembelajaran efektif adalah pembelajaran yang ada di kelas.

\section{Daftar Rujukan}

Arifuddin. "Pemikiran-Pemikiran Fonetik Ibnu Jinni (W. 392 H./1002 M.).” Jurnal CMES 6, no. 2 (2013): 146-63.

Djamarah, Syaiful Bahri, dan Aswan Zain. Strategi belajar mengajar. Jakarta: Rineka Cipta, 2010.

Effendy, Ahmad Fuad. Metodologi Pengajaran Bahasa Arab. Malang: Misykat, 2005. 
Hermawan, Acep. Metodologi Pembelajaran Bahasa Arab. Bandung: PT Remaja Rosdakarya, 2011.

Mariyana, Rita. Pengelolaan lingkungan belajar. Jakarta: Prenada Media Grup, 2010.

Nuha, Ulin. Metodologi Super Efektif Pembelajaran Bahasa Arab. Yogyakarta: Diva Press, 2012.

Pringgawidagda, Suwana. Strategi Penguasaan Bahasa. Yogyakarta: Adicita Karya Nusa, 2002.

Purba, Andiopenta. "Peranan lingkungan bahasa dalam pemerolehan bahasa kedua." Pena: Jurnal Pendidikan Bahasa dan Sastra 2, no. 2 (2013).

Rosyidi, Abdul Wahab, dan Mamlu'atul Ni'mah. Memahami Konsep Dasar Pembelajaran Bahasa Arab. UIN-Maliki Press, 2011.

Sadat, Anwar. "Lingkungan Bahasa sebagai Media Pembelajaran Bahasa Arab (Ikhtiar membangun Pembelajaran Yang Efektif dan Produktif)." $A L$ AF'IDAH: Jurnal Pendidikan Bahasa Arab dan Pengajarannya 1, no. 1 (2017): 4-29.

Subana, dan Sudrajat. Dasar-dasar Penelitian Ilmiah. Bandung: Pustaka Setia, 2005.

Sumaryanti, Lilis. "Peran Lingkungan terhadap Perkembangan Bahasa Anak." Muaddib: Studi Kependidikan dan Keislaman 7, no. 01 (2017): 72-89. 